\title{
Role of Communities to Prevent Corneal Blindness
}

\author{
Tariq Masood* \\ Tree Tops The Eye Centre, Pakistan
}

Submission: December 12, 2017; Published: January 22, 2018

*Corresponding author: Tariq Masood, General Manager, Tree Tops The Eye Centre, 3F/1 Wapda Town, Lahore, Pakistan, Tel: +923246161786; Email: tariq@treetopseye.com

\section{Short Communication}

The community needs to take appropriate actions itself, as well as actions by government and non-governmental organizations. Prevention of corneal blindness can take place at three stages:

a) Level-1 Prevention: Actions taken to prevent the onset of disease

b) Level-2 Prevention: Actions taken to prevent complications and the development of visual disability due to an existing disease

\section{c) Level-3 Prevention}

After the immediate resolution of the problem by surgery or other treatment, actions should be taken to reduce existing disability from disease complications right up to the point when some patient either seen by an eye care worker or admitted to hospital, the community should influence and trace out the ground reality or the actual reasons. An eye care worker must have little control over the following:

i. The risk factors and immediate medical causes

ii. The contributing and social factors.

The community has the capacity to influence these factors, either through change in the behavior of individuals, or by bringing improvements at the community level. The eye care worker's role is very vital when they participating in programmes to reduce corneal blindness. Progressive and active campaign of community awareness will ultimately result to build up a role of active partner in the prevention of corneal blindness.

\section{First steps}

A model prevention programme does address the complete list of causes of corneal blindness in the community rather it aim community to understand and build on their existing knowledge, and encourage them to support a programme to avail existing services available and build upon the better ongoing services. This kind of approach is progressive and would help to understand the community the upcoming needs. Situation analysis help to design the needs and programmes to involve community right from the start, it would also help the community to identify any gaps in your knowledge so that those could be filled.

There are few questions to keep in mind before designing a awareness programme.

a) Q-What are the community's knowledge and perceptions regarding the causes and treatment of corneal blindness.

b) Q-What are the prevailing methods of communication within the community?

c) Q- How we can utilize present systems effectively to transmit the new awareness message.

d) Q- How we can take benefit of current community knowledge and perceptions.

e) Q- What kind of expertise and skills exist within the community that may be exercised to design a effective awareness programme.

\section{PP-Primary Prevention}

The deficiency of vitamin-A and eye injuries are directly relevant to corneal blindness. Corneal blindness is also associated with some there socio/economy factors. For example inadequate water supply and sanitation, poor nutrition, and pathetic agricultural practices. Inadequate supplies and cost of medicine particularly in low line areas contribute hugely in corneal blindness.

An effective programme and comprehensive plans should support the community to obtain the health care needs, either by asking community help and sources or by using government resources and infrastructure. The programme should provide health education to address socio/economy factors and methods to avoid corneal blindness. The close collaboration between health units and national health system which will strengthen the programme. Good and effective communication is most essential tool and part between different health units. Village elders and Government official can play a significant role to obtain 
desirable results. Where as in urban areas other marketing tools like use of media and billboards can be effective contributing factors. A health messages into the school curriculum is another possibility.

\section{SP-Secondary Prevention}

Patients with corneal disease or injuries are usually in pain and may suffer from photophobia. Their eyes could be watery and they may have blurred vision as well. Generally in rural areas people having serve pain, may go for self-medication Such practices always delay the process of obtaining correct and in time treatment which may result corneal opacity or visual loss.

\section{Strengthen health systems}

The strength of prevailing health system is important if the health units make best use of it to prevent corneal blindness and build new programme to strengthen the system without over loading it. The objective of a new programme should eliminate the weak and opportunity areas or to replace those with fresh and effective means to get the best use of it. Many health and community development programmes already exists in community through health units like measles immunization,

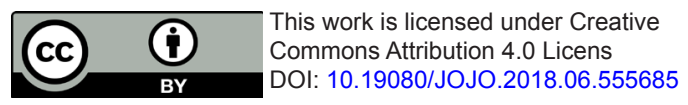

perinatal care, nutrition, water supply, and sanitation, It is important to get best benefit of these programmes by informing competent authorities and policy makers and funding agencies to extend help in prevention of corneal blindness..

Data gathering from the affected areas will to improve programme design and service. It is also important to ensure that the emergency eye care for corneal infections or trauma, particularly in children, is free.. Encourage communities to take the lead on health matters, for example by working with community development groups. Even the general public can take responsibility for a range of interventions and support to led health activities such as face washing to demanding better services. Motivate and support communication between the community and decision makers within the health system, as well as between different groups or specialties in the health system.

\section{Conclusion}

As an eye health worker one should understand both the medical causes of corneal scarring, and the non-medical and social factors that lead to corneal blindness.

\section{Your next submission with Juniper Publishers will reach you the below assets}

- Quality Editorial service

- Swift Peer Review

- Reprints availability

- E-prints Service

- Manuscript Podcast for convenient understanding

- Global attainment for your research

- Manuscript accessibility in different formats

( Pdf, E-pub, Full Text, Audio)

- Unceasing customer service

Track the below URL for one-step submission https://juniperpublishers.com/online-submission.php 